\title{
Strategi pembelajaran jarak jauh di SMP Plus Daarul Ahgaff dalam situasi wabah pandemi COVID- 19
}

\author{
Dita Atika Sari \& Abdul Khamid \\ Institut Agama Islam Negeri Salatiga, Indonesia \\ ditaatikasari106@gmail.com
}

\begin{abstract}
The research aims to find out about the long-distance learning strategy during the COVID-19 pandemic at junior high school plus Daarul Ahgaff. Then the supporting factors of the performance of long-distance learning, and the slowdown factors. The study involves a qualitative approach. Primary data are collected using the Google form and secondary data from related articles and literature. From the study, it is known that long-range learning strategies utilize online technology as a learning medium. The contributing factors include learning activities online, enhancing teachers' and students' ability to harness technology, and enhancing teacher and disciple creativity. And not all students have android phones, no direct interaction of teachers and students, and his fees will be internet expenses.
\end{abstract}

Keywords: COVID-19; distance education; teacher

\begin{abstract}
Abstrak
Tujuan dari penelitian untuk mengetahui tentang strategi pelaksanaan pembelajaran jarak jauh pada masa pandemi COVID-19 di SMP Plus Daarul Ahgaff. Lalu faktor pendukung dari pelaksanaan pembelajaran jarak jauh, dan faktor penghambatnya. Penelitian ini menggunakan pendekatan kualitatif. Data primer dikumpulkan menggunakan Google form dan data sekunder dari artikel dan literatur terkait. Dari penelitian tersebut diketahui, strategi pembelajaran jarak jauh memanfaatkan teknologi daring sebagai media pembelajaran. Adapun faktor pendukung di antaranya adanya aktivitas pembelajaran secara daring, meningkatkan kemampuan para guru dan murid dalam memanfaatkan teknologi, dan meningkatkan kreativitas guru serta murid. Dan faktor penghambat tidak semuanya siswa memiliki HP android, tidak adanya interaksi langsung Guru dan murid, dan borosnya akan pengeluaran biaya internet.
\end{abstract}

Kata Kunci: COVID-19; guru; Pembelajaran Jarak Jauh

Diserahkan: 29-05-2021 Disetujui: 08-06-2021. Dipublikasikan: 08-06-2021

Kutipan: Sari, D., \& Khamid, A. (2021). Strategi Pembelajaran Jarak Jauh Sekolah Menengah Pertama Plus Daarul Ahgaff dalam Situasi Wabah Pandemi Covid-19. Ta'dibuna: Jurnal Pendidikan Islam, 10(2), 74-85. doi: http://doi.org/10.32832/tadibuna.v10i2.4775 


\section{Pendahuluan}

Pada masa sekarang ini ilmu pengetahuan serta teknologi berkembang sangat pesat, dan sangat berpengaruh terhadap bidang kehidupan termasuk bidang pendidikan. Dalam UU Sistem Pendidikan Nasional nomor 20 tahun 2003 pendidikan merupakan usaha sadar dan terencana untuk mewujudkan suasana belajar dan pembelajaran agar peserta didik secara aktif mengembangkan potensi dirinya untuk memiliki kekuatan spiritual keagamaan, pengendalian diri, kepribadian, kecerdasan, akhlak mulia, serta keterampilan yang diperlukan dirinya, masyarakat, bangsa, dan negara (Fatimah \& Andriyansyah, 2013, hlm. 6). Pendidikan merupakan interaksi terorganisasi berkelanjutan yang dirancang untuk menumbuhkan kegiatan belajar pada diri seseorang (Munir, 2009, hlm. 1). Kegiatan belajar dapat dilakukan di mana pun dan kapan pun, tidak terbatas ruang dan waktu.

Dunia sedang di uji dengan permasalahan kesehatan yaitu pandemi COVID-19 yang sangat berpengaruh terhadap semua aspek kehidupan. Untuk mencegah meluasnya penularan COVID-19 pada warga sekolah, Kementerian Pendidikan dan Kebudayaan (Kemendikbud) mengeluarkan surat edaran Nomor 4 Tahun 2020 tentang pelaksanaan kebijakan penyebaran COVID-19 yang antara lain memuat arahan tentang proses belajar dari rumah. Untuk melindungi warga sekolah dari penularan COVID-19 maka pemerintah pusat maupun daerah memberikan kebijakan untuk melaksanakan pembelajaran jarak jauh (PJJ). Pembelajaran jarak jauh merupakan pendidikan yang menggunakan media sebagai sumber pembelajaran tanpa mengharuskan adanya pertemuan pendidik dengan peserta didik dalam satu kelas pada waktu yang sama (Fatimah \& Andriyansyah, 2013, hlm. 7). Dalam proses pembelajaran jarak jauh ini perlu adanya kesiapan baik dari pendidik maupun peserta didik, entah dari segi perencanaan pembelajaran, sumber belajar, serta jaringan internet yang stabil sehingga pembelajaran jarak jauh dapat berjalan dengan maksimal (Munir, 2009, hlm. 4). Dalam pelaksanaan pembelajaran jarak jauh suasana pembelajaran seperti sarana dalam kelas sangat penting untuk diciptakan dalam pembelajaran ini. Sistem komunikasi pun harus baik, agar fungsi pendidikan jarak jauh dapat dijalankan (Sutopo, 2012, hlm. 6), dengan demikian pembelajaran jarak jauh dapat berjalan dengan maksimal.

Untuk mengatasi keterbatasan pembelajaran jauh, maka pembelajaran dilengkapi dengan media yang dapat mendukung terjadinya interaksi antara pendidik dan peserta didik sehingga pembelajaran dapat berjalan dengan efektif (Munir, 2009, hlm. 9). Sebagai komponen sistem pembelajaran, media memiliki fungsi yaitu sebagai komponen yang dimuati pesan pembelajaran untuk disampaikan kepada siswa (Sudatha \& Tegeh, 2015, hlm. 5). Semakin berkembangnya teknologi, media yang digunakan dalam pembelajaran jarak jauh beragam seperti internet, email, telepon, audio, dan video (Munir, 2009, hlm. 9). Interaksi antara pendidik dan peserta didik dapat dilakukan dengan menggunakan media terebut tanpa harus bertatap muka secara langsung. Demikian juga peserta didik 
dapat memperoleh informasi dalam lingkup yang luas dari berbagai sumber melalui cyber space atau ruang maya dengan menggunakan media internet (Sutopo, 2012, hlm. 17).

Agar mendapatkan hasil yang maksimal dari pembelajaran jarak jauh ini seorang guru/pengajar hendaknya memiliki strategi-strategi pembelajaran yang terencana. Strategi pembelajaran merupakan perpaduan dari urutan kegiatan, cara pengorganisasian materi, metode dan teknik pembelajaran, dan media pembelajaran yaitu berupa peralatan dan bahan pelajaran, serta waktu yang digunakan dalam proses pembelajaran untuk mencapai tujuan yang ditentukan (Arsa, 2015, hlm. 7). Strategi memiliki peranan penting dalam suatu proses pembelajaran, karena strategi pembelajaran menjadi faktor utama bagi peningkatan proses pembelajaran. Bagi pendidik/ guru strategi dapat dijadikan sebagai pedoman acuan bertindak yang sistematis dalam pelaksanaan mengajar (Hardini \& Puspitasari, 2015, hlm. 2). untuk dapat mengelola dan merancang strategi pembelajaran, seorang pengajar hendaknya mengenal faktor-faktor penentu kegiatan pembelajaran tersebut sehingga terlaksanalah pembelajaran yang efektif dan efisien (Remiswal \& Amelia, 2013, hlm. 34). Dimasa sekarang ini banyak sekali strategi pembelajaran jarak jauh yang dapat dilakukan oleh guru/ pengajar, yaitu dengan memanfaatkan teknologi yang telah tersedia. Namun dalam pembelajaran jarak jauh pastilah tidak semudah ketika melakukan pembelajaran konvensional seperti yang sudah biasa di lakukan. Seperti yang terjadi di SMP Plus Daarul Ahgaff. Di masa pandemi COVID-19 ini di SMP Plus Daarul Ahgaff termasuk sekolah yang melaksanakan pembelajaran jarak jauh. Namun dalam pelaksanaan pembelajaran jarak jauh, sering kali ditemukan kendala atau ketidaksesuaian dengan pembelajaran yang seharusnya, banyak yang mengira tanggung jawab pengajar dalam melaksanakan PJJ jauh lebih ringan dibandingkan dengan pembelajaran tradisional (Semradova \& Hubackova, 2016). Tidak berbeda dari pembelajaran tradisional, dalam pembelajaran jarak jauh juga muncul hambatan seperti jaringan internet yang kurang mendukung, sumber daya yang kurang memadai, kesiapan personal dari guru maupun siswa dan sebagainya. Untuk mengatasi hambatan- hambatan tersebut setiap guru memiliki strategi yang berbeda. Strategi pembelajaran terdiri atas semua komponen materi pelajaran dan prosedur yang akan digunakan untuk membantu siswa mencapai tujuan pembelajaran tertentu (Anitah, 2014, hlm. 3).

Pembelajaran jarak jauh telah menjadi tantangan bagi dunia pendidikan. Aspek penting dalam meningkatkan keterampilan pembelajaran jarak jauh harus ditingkatkan di antaranya dengan program pelatihan guru-guru dalam penggunaan teknologi informasi dan komunikasi. Untuk kelancaran dalam pembelajaran jarak jauh, guru tidak cukup hanya memiliki keterampilan teknologi dasar (seperti menggunakan komputer dan tersambung ke internet), tetapi juga pengetahuan untuk menggunakan perangkat rekaman dan perangkat lunaknya, serta metode untuk menyampaikan pelajaran tanpa 
interaksi tatap muka (video pembelajaran yang menarik). Keterampilan tersebut akan diperlukan ketika akan menggunakan platform belajar daring (online). Lebih penting lagi, kesenjangan antara skenario pelatihan dan eksekusi di lapangan perlu untuk diminimalisasi (Azzahra, 2020).

Proses PJJ idealnya tetap dapat mengakomodasi kebutuhan belajar siswa untuk mengembangkan bakat dan minat sesuai dengan jenjang pendidikannya. Untuk mewujudkan hal tersebut diperlukan kesiapan pendidik, kurikulum yang sesuai, ketersediaan sumber belajar, serta dukungan peranti dan jaringan yang stabil sehingga komunikasi antar peserta didik dan pendidik dapat efektif. Kondisi PJJ saat ini belum dapat disebut ideal sebab masih terdapat berbagai hambatan yang dihadapi. Hambatan tersebut sekaligus menjadi tantangan dalam pelaksanaan PJJ mengingat pelaksanaan PJJ merupakan keharusan agar kegiatan pendidikan tetap dapat terselenggara di tengah darurat pandemi COVID-19 yang terjadi saat ini. Hambatan yang dihadapi sekaligus menjadi tantangan dalam pelaksanaan PJJ antara lain berkaitan dengan kesiapan sumber daya manusia, kurang jelasnya arahan pemerintah daerah, belum adanya kurikulum yang tepat, dan keterbatasan sarana dan prasarana, khususnya dukungan teknologi dan jaringan internet. Kesiapan sumber daya manusia meliputi pendidik, peserta didik, dan dukungan orang tua merupakan bagian terpenting dalam pelaksanaan PJJ.

Menurut penelitian (Yuangga \& Denok, 2020) tentang Pengembangan Media dan Strategi Pembelajaran Untuk Mengatasi Permasalahan Pembelajaran Jarak Jauh di Pandemi COVID-19 menyimpulkan bahwa permasalahan pembelajaran jarak jauh secara online di pandemi ini berkaitan dengan banyaknya ketidaksiapan antara siswa dengan guru, hal tersebut dikarenakan siswa harus dapat memahami materi dengan sendirinya tanpa penjelasan langsung dari guru, begitu pula di keadaan pandemi ini siswa harus mempersiapkan biaya ekstra untuk menyiapkan kuota agar dapat mengikuti pembelajaran secara online dengan jadwal yang padat. Sedangkan guru harus mampu menyampaikan materi dengan cara yang efektif sehingga mampu diakses melalui jarak jauh.

Berdasarkan hal tersebut, maka peneliti merasa tertarik untuk mengetahui lebih lanjut strategi pembelajaran jarak jauh yang diterapkan oleh guru di SMP Plus Daarul Ahgaff di masa pandemi COVID-19. Permasalahan yang akan dikaji adalah (a) bagaimana strategi yang diterapkan dalam situasi pandemi COVID-19, dan (b) bagaimana faktor pendukung dan penghambat pembelajaran jarak jauh dalam situasi pandemi COVID-19.

\section{Metode Penelitian}

Jenis penelitian ini menggunakan pendekatan kualitatif (qualitative research), yaitu penelitian yang ditujukan untuk mendeskripsikan dan menganalisis fenomena, peristiwa, aktivitas sosial, sikap, kepercayaan, persepsi, pemikiran orang secara individu maupun 
kelompok (Sukmadinata, 2010, hlm. 60-61) di mana data yang disajikan tidak dalam bentuk angka-angka melainkan dalam bentuk kata-kata dan gambaran-gambaran (Bungin, 2005, hlm. 103), sehingga hasil penelitiannya berupa deskripsi, interpretasi bagaimana tentang Strategi Pembelajaran jarak jauh SMP Plus Daarul Ahgaff dalam kondisi pandemi COVID-19. Ukuran sampel didasarkan pada pencapaian kedalaman dan kekayaan deskripsi. Penelitian ini dilakukan terbatas pada 10 responden terdiri dari Bapak/ Ibu guru SMP Plus Daarul Ahgaff yang dipilih secara acak. Peneliti menggunakan angket dalam bentuk tautan Google form: https:form.gle/ArTnfBVTBN47gay7 yang disebarkan melalui whatsapp. Sedangkan data sekunder dikumpulkan dari data yang dipublikasikan seperti artikel, jurnal-jurnal dan buku terkait.

Dalam tulisan ini penulis menggunakan beberapa langkah yang berkaitan dengan metode penelitian tersebut yaitu: pertama, memberikan tautan Google form kepada seluruh responden untuk mengisi. Tahap kedua adalah melakukan pengamatan dan pencatatan dari sistematika fenomena-fenomena yang diselidiki (Sutrisno, 2003, hlm. 136) Peneliti melakukan pengamatan secara tidak langsung karena mengikuti anjuran pemerintah untuk social distancing. Ketiga, peneliti melakukan dokumentasi guna mencari data yang relevan serta memperkuat data lapangan yang telah diperoleh berupa penelitian terdahulu, artikel, atau buku yang terkait (Arikunto, 2002, hlm. 148). Analisis data dalam penelitian ini terdiri dari: pertama, penyajian data yaitu dengan mendeskripsikan hasil data yang diperoleh melalui angket (Google form) dengan menggunakan kalimat dengan pendekatan kualitatif, sehingga diperoleh laporan yang sistematis dan mudah untuk dipahami. Kedua, mereduksi data angket yang terkumpul dengan merujuk pada fokus utama, untuk kemudian dicari tema dan polanya (Sugiyono, 2010, hlm. 247). Ketiga, yaitu penarikan kesimpulan dari hasil pengumpulan data kemudian direduksi dan diverifikasi. Setelah melakukan verifikasi, tahap selanjutnya adalah mencari kesimpulan akhir.

Teknik pengujian validitas data yang digunakan dalam penelitian ini menggunakan triangulasi untuk menguji keabsahan dengan memanfaatkan suatu yang lain dari data itu sendiri (Moelong, 2009, hlm. 330). Dalam penelitian ini teknik triangulasi yang digunakan yaitu: triangulasi data yaitu mengumpulkan data yang sejenis dari beberapa sumber data yang berbeda dan triangulasi metode dilakukan dengan menggali data yang sama dengan metode yang berbeda.

\section{Hasil dan Pembahasan}

\section{A. Temuan penelitian}

SMP Plus Daarul Ahgaff yang berada di kecamatan Pabelan Kabupaten Semarang merupakan salah satu lembaga pendidikan yang terkena imbas adanya wabah COVID-19. Himbauan dari pemerintah untuk memindahkan tempat belajar mengajar, yang semula 
di kelas dialihkan belajar dari rumah masing-masing siswa-siswi. Tujuan dari penelitian ini yaitu untuk mendapatkan informasi mengenai Strategi PJJ SMP Plus Daarul Ahgaff dalam masa pandemi COVID-19. Semua tanggapan narasumber asli dan mereka telah dikutip sebagaimana dinyatakan oleh para responden.

Setelah melakukan penelitian menggunakan angket (Google form), diperoleh beberapa pernyataan yang disampaikan oleh para responden sebagai berikut:

Responden DAK memberikan tanggapan tentang strategi Pembelajaran Jarak Jauh SMP Plus dalam situasi COVID-19: "Siswa-siswi tidak diperkenankan ke Sekolahan lebih dulu akan tetapi tetap bisa mengikuti pembelajaran walaupun jarak jauh melalui HP android".

Senada dengan responden di atas, FRN memberikan tanggapan: "Pembelajaran jarak jauh melalui daring mengasyikkan juga dengan ikut serta memanfaatkan perkembangan teknologi yang semakin pesat kemajuannya".

Pernyataan di atas memberikan gambaran bahwa PJJ bukan menjadi penghambat penyampaian materi namun dengan memanfaatkan teknologi daring materi pembelajaran dapat tersampaikan dan siswa-siswi masih dapat belajar walau dari rumah. Menambah kecakapan penggunaan teknologi daring dengan baik, terlebih hal tersebut merupakan suatu yang baru atau belum pernah dilakukan. Selain itu, strategi pembelajaran yang demikian menjadikan para Siswa-siswi menjadi semakin tertarik untuk mengikuti pembelajaran serta menantang para Bapak/Ibu Guru untuk menyiapkan materi pembelajaran yang inovatif dan kreatif.

Sebagaimana pendapat dari JRS,

"Sekarang lebih mudah memanfaatkan teknologi pembelajaran bisa menggunakan, grup WA, email, Google form, Google classroom dll, memberi link untuk penugasan, memberi nilai dari penugasan dan absensi via WA.

Responden HRT memberikan pernyataan: "dalam situasi seperti ini siswa-siswi tidak hanya bermain saja, siswa-siswi tetap bisa belajar walaupun di rumah, Bapak/Ibu Guru tetap menyediakan ruang diskusi atau penyampaian materi melalui tayangan video, WAG, Google classroms dll.

Pemanfaatan teknologi dan media daring dalam pembelajaran PJJ di SMP ini, tidak hanya sebatas memberikan tugas saja namun dapat juga melaksanakan aktivitas yang seperti biasa dilakukan di Sekolahan.

Responden lainnya memberikan tanggapan berkenaan dampak positif dan dampak penghambat pelaksanaan PJJ dalam masa pandemi COVID-19 terhadap siswa-siswi SMP plus Daarul Ahgaff. 
KSL memberikan tanggapan: "walaupun anak di rumah tetap bisa belajar dengan bimbingan guru, ketika melakukan praktik bahannya lebih banyak karena media d rumah lebih banyak, waktu pengerjaannya pun lebih lama tidak dibatasi jam waktu seperti disekolah dan siswa-siswi lebih mandiri"

UST memberikan tanggapan berkenaan dampak positif pelaksanaan pembelajaran jarak jauh: "Bagi beberapa guru siswa bisa menjadikan penambah wawasan dan skill dalam hal teknologi"

Responden lainya memberikan tanggapan (AGS): "Terjadinya kolaborasi orang tua siswa dan guru dalam ikut serta membimbing dan mengarahkan putra-putrinya dalam mencari ilmu".

Diikuti dengan tanggapan dari JNR: "Tidak pergi jauh ke sekolahan, menghemat tenaga dan biaya transportasi, waktunya lebih longgar, bisa dikerjakan walaupun sedang melakukan aktivitas lainya.

Pernyataan di atas memberikan gambaran bahwa dimasa wabah pandemi COVID-19 baik Bapak/Ibu Guru serta siswa-siswi tetap bisa melaksanakan kegiatan belajar mengajar walaupun dengan berbagai tantangan tidak melemahkan para Bapak/Ibu Guru serta siswa-siswi untuk terus belajar dengan baik dan memahami materi-materi yang diberikan oleh Bapak/Ibu Guru, serta menambah daya kreativitas seorang pendidik yang harus serba bisa dalam kondisi apa pun dan bahan media adapun tetap melaksanakan pembelajaran walaupun belajar dari rumah adalah solusi yang baik dengan harapan memutus rantai penyebaran wabah pandemi COVID-19.

Selain dampak positif ada pula dampak penghambat adanya pembelajaran jarak jauh dimasa pandemi COVID-19 dengan adanya pelaksanaan penyampaian materi melalui daring, beberapa responden memberikan pernyataan sebagai berikut:

DYH memberikan tanggapan: "Tidak semua siswa memiliki HP android, kekuatan sinyal juga menentukan cepat atau lambatnya dalam proses PJJ serta borosnya akan pengeluaran pembelian kuota internet"

Responden lainnya memberikan tanggapan FRH bahwa: "Tidak adanya interaksi langsung antara siswa dengan guru, sehingga penangkapan sebagian anak tidak sama dengan harapan guru, dan juga tidak semua anak di daerahnya mempunyai sinyal jaringan yang bagus"

Secara keseluruhan para Bapak/Ibu Guru serta siswa-siswi merasakan dampak positif dengan diadakannya pembelajaran jarak jauh yang diberikan oleh pihak sekolahan namun, sebagaimana pendapat di atas bahwa masih di dapatinya adanya hambatan dalam proses melaksanakan pembelajaran berbasis daring tersebut dan perlunya pengkajian serta sebagai bahan evaluasi ke depannya.

\section{B. Pembahasan}




\section{Strategi PJJ dalam situasi Wabah Pandemi COVID-19 SMP Plus Daarul Ahgaff}

Pada mulanya strategi digunakan dalam dunia militer yang diartikan sebagai cara penggunaan seluruh kekuatan militer untuk memenangkan suatu peperangan. Berkembang dalam dunia pendidikan strategi pembelajaran dapat diartikan sebagai perencanaan yang berisi tentang rangkaian kegiatan yang didesain untuk mencapai tujuan pendidikan tertentu (Wina Sanjaya: 2014, hlm. 127).

Maka pembelajaran yang diterapkan guru akan tergantung pada pendekatan yang digunakan: sedangkan bagaimana menjalankan strategi itu dapat diterapkan berbagai metode pembelajaran. Dalam upaya menjalankan upaya metode pembelajaran seorang guru dapat menentukan strategi yang dianggapnya relevan dengan metode, dan penggunaan teknik setiap guru mempunyai berbeda dari satu ke lainnya.

Wabah pandemi COVID-19 atau yang biasa disebut dengan Corona membuat banyak segala sektor mengalami perubahan, termasuk dalam dunia pendidikan dari tingkat paling bawah sampai ke tingkat paling atas mengalami perubahan dalam cara pembelajaran, yang mulanya semua kegiatan belajar mengajar dilakukan di kelas saat ini semua kegiatan tersebut diliburkan dan semua siswa diliburkan dan digantikan dengan pembelajaran Daring dari rumah masing-masing. Dalam pembelajaran ini pastinya membutuhkan kesiapan antara semua lapisan baik Guru, siswa-siswi dan strategi baru dalam menerapkan pembelajaran Daring yang belum pernah dilakukan sebelumnya dengan tetap mengedepankan dan memperhatikan pemahaman materi siswa-siswi. Bagaimanapun juga pembelajaran secara Daring membutuhkan bantuan teknologi yang mumpuni dan dapat diakses dengan mudah, dengan adanya itu maka SMP Plus Daarul Ahgaff berkoordinasi dan memutuskan untuk melaksanakan pembelajaran secara Daring dengan berbagai strategi diserahkan kepada Bapak/Ibu Guru masing-masing sehingga pembelajaran tetap berjalan.

Poin utama yang ditekankan kepada guru selama PJJ adalah harus mampu menciptakan situasi belajar yang menyenangkan sehingga materi yang diajarkan dapat diterima dengan baik. Oleh karena itu, demi menunjang kegiatan belajar mengajar secara daring, guru diharapkan mampu berpikir kreatif menciptakan media belajar yang menunjang pelaksanaan pembelajaran (Zaitun, 2020, hlm. 3).

Seperti halnya pelaksanaan pembelajaran secara konvensional, pembelajaran daring juga membutuhkan strategi agar pembelajaran dapat berlangsung secara optimal. Ini ditandai dengan adanya koordinasi yang baik antara Guru dan siswa. Beberapa guru bahkan memiliki grup whatsapp khusus, sesuai dengan kelas yang diampu. Sedangkan, sudah menjadi kebiasaan umum jika setiap kelas memiliki grup whatsapp yang terdiri dari siswa-siswi dalam satu kelas. Dari pengamatan peneliti, penjelasan di atas merupakan bentuk strategi sebelum pelaksanaan pembelajaran daring diadakan. 
Beberapa strategi yang di terapkan dalam PJJ SMP Plus Daarul Ahgaff selama situasi COVID-19 pembelajaran tatap muka ditiadakan digantikan dengan belajar jarak jauh menggunakan pendekatan perkembangan teknologi, walaupun pertama melaksanakan pembelajaran jarak jauh membutuhkan kesiapan yang lebih dari pihak Guru ataupun murid untuk tetap menunjang pembelajaran jarak jauh ini, dengan adanya pandemi COVID-19 ini banyak dari lembaga pendidikan melaksanakan pembelajaran jarak jauh dan diikuti SMP Plus Daarul Ahgaff menerapkan pembelajaran jarak jauh dengan menggunakan beberapa strategi di antaranya: pembelajaran dilaksanakan dengan pemanfaatan teknologi yang berkembang saat ini seperti WAG, Google classroom, Google form, video. Aplikasi tersebut dipilih karena dapat digunakan sesuai kebutuhan penggunanya. WhatsApp dapat mengirim pesan teks, pesan suara dan video, berbagi berbagai gambar, video, dokumen materi pembelajaran dan lainnya. Aplikasi Google classroom fungsinya sama seperti WhatsApp tetapi aplikasi tersebut biasa digunakan untuk diskusi dan mengirim tugas agar lebih mudah dan rapi, sedangkan aplikasi Meet dan Zoom untuk pertemuan tatap muka secara daring agar pengajar dapat melihat wajah siswanya yang memperhatikan pengajar saat memberikan penjelasan materi. Semuanya strategi pembelajaran tersebut dikoordinasikan sebelumnya kepada pihak orang tua wali sehingga dalam hal ini Bapak/Ibu Guru tetap memberikan pembelajaran dan murid bisa mengikutinya dari rumah masing-masing (Kharisma \& Denok, 2020, hlm. 54).

PJJ bukan menjadi penghambat penyampaian materi namun dengan memanfaatkan teknologi daring materi pembelajaran dapat tersampaikan dan siswa-siswi masih dapat belajar walau dari rumah. Menambah kecakapan penggunaan teknologi daring dengan baik, terlebih hal tersebut merupakan suatu yang baru atau belum pernah dilakukan. Selain itu, strategi pembelajaran yang demikian menjadikan para Siswa-siswi menjadi semakin tertarik untuk mengikuti pembelajaran serta menantang para Bapak/Ibu Guru untuk menyiapkan materi pembelajaran yang inovatif dan kreatif.

Dengan demikian siswa-siswi selama pandemi COVID-19 ini tidak hanya santai-santai terdiam di rumah saja, selain bisa membantu orang tua, lebih dekat dengan orang tua dan pastinya bisa tetap belajar, jikalau ada sebagian siswa yang kurang paham bisa ditanyakan melalui grup yang sudah disediakan oleh pihak sekolahan, hal ini dirasa cukup bagus untuk tetap syiar menyampaikan ilmu di tengah-tengah wabah pandemi COVID-19 yang mengguncang bukan hanya di Indonesia melainkan dunia.

\section{Dampak Positif PJJ dalam situasi Wabah Pandemi COVID-19 SMP Plus Daarul Ahgaff}

Wabah pandemi COVID-19 yang melanda terkhusus Indonesia saat ini hampir semua warga Negara di Nusantara merasakan kekhawatiran yang sangat luar biasa bahkan selalu dibayang-bayangi dengan berbagai informasi melalui berbagai sumber. Meskipun kurang nyaman dengan kondisi saat ini, para Bapak/Ibu Guru dan murid masih bisa 
merasakan dampak positif dari pembelajaran daring, karena setiap kejadian ada sebuah hikmah dan dampak positif yang bisa kita semua rasakan, dari sini penulis mencoba untuk menguraikan dari hasil penelitiannya sebagian dampak positif dari pandemi COVID-19 SMP Plus Daarul Ahgaff. Pertama: Pembelajaran daring menaati perintah aturan pemerintah sebagai wujud pemutusan rantai penyebaran virus COVID-19, dengan tidak adanya pembelajaran tatap muka dan menghindari dari kerumunan banyak orang. Kedua, Menambah wawasan terkait penggunaan teknologi/aplikasi, adanya wabah ini memberikan kesempatan bagi guru atau murid untuk lebih mengenal lagi dunia teknologi sebagai media untuk menambah ilmu dalam melaksanakan pembelajaran, raga tidak bertatap muka, melainkan pembelajaran tetap berjalan dengan bantuan media teknologi serta antara guru dan peserta didik dapat berkomunikasi secara mudah melalui fasilitas internet tanpa dibatasi oleh jarak, tempat, waktu (Rusman, 2011, hlm. 351). Ketiga, Bahan praktik lebih banyak, hal ini di rasa sangat benar jika ada sebuah praktik pembuatan kerajinan semisal, guru dan siswa lebih mudah mendapatkan bahan yang didapatkannya di rumah. Keempat, menghemat biaya transportasi ke Sekolahan dengan hanya berbekal HP, laptop pembelajaran bisa berjalan dan waktunya lebih fleksibel.

Dengan demikian dimasa wabah pandemi COVID-19 baik Bapak/Ibu Guru serta siswa-siswi tetap bisa melaksanakan kegiatan belajar mengajar walaupun dengan berbagai tantangan tidak melemahkan para Bapak/Ibu Guru serta siswa-siswi untuk terus belajar dengan baik dan memahami materi-materi yang diberikan oleh Bapak/Ibu Guru, serta menambah daya kreativitas seorang pendidik yang harus serba bisa dalam kondisi apa pun dan bahan media adapun tetap melaksanakan pembelajaran walaupun belajar dari rumah adalah solusi yang baik dengan harapan memutus rantai penyebaran wabah pandemi COVID-19.

\section{Faktor Penghambat PJJ dalam situasi Wabah Pandemi COVID-19 SMP Plus Daarul Ahgaff}

Indonesia adalah salah satu Negara yang turut terkena imbas wabah pandemi COVID19 yang terjadi hampir di seluruh dunia, wabah pandemi COVID-19 menyebabkan Indonesia turut mengeluarkan beberapa himbauan kepada publik, seperti halnya seruan gerakan Work Form Home (WFH), dan pembelajaran daring yang dilaksanakan hampir seluruh lembaga pendidikan yang ada di Indonesia. Diambil dari sudut pandang Bapak/Ibu Guru pembelajaran daring merupakan salah satu metode baru yang belum lumrah digunakan di SMP Plus Daarul Ahgaff.

Berdasarkan penelitian penulis terdapat beberapa hambatan dalam pelaksanaan pembelajaran daring, bagaimanapun juga setiap pembelajaran pasti didapatkan sisi faktor penunjang dan faktor penghambatnya apalagi dalam dunia pendidikan yang belum pernah dilakukan selama ini dalam pembelajaran perlunya beradaptasi lebih berkenaan penggunaan media pembelajaran berbasis teknologi, dari sini penulis mencoba untuk 
menguraikan dari hasil penelitian dampak penghambat dalam pelaksanaan PJJ SMP Plus Daarul Ahgaff Pertama: Tidak semua siswa memiliki HP android, kekuatan sinyal juga menentukan cepat atau lambatnya dalam proses PJJ. Dalam belajar daring, mereka harus bergantian HP dengan orang tua, dan mendapat giliran setelah orang tua pulang kerja. Ada yang pulang di siang hari, sore hari, bahkan malam hari. Sementara itu umumnya jadwal pembelajaran daring di sekolah dilakukan mulai pagi hari hingga siang hari (Asmuni, 2020, hlm. 284). Kedua: Tidak adanya interaksi langsung antara guru dengan siswa, sehingga penangkapan sebagian anak tidak sama dengan harapan guru, dan juga tidak semua anak di daerahnya mempunyai sinyal jaringan yang bagus. Tidak sedikit peserta didik yang kesulitan mengikuti pembelajaran karena letak tempat tinggalnya belum terjamah oleh akses internet sehingga mengakibatkan pembelajaran secara daring sangat sukar dilaksanakan (Zaitun, 2020, hlm. 4). Ketiga: Borosnya akan pengeluaran pembelian kuota internet baik dari pihak Bapak/Ibu Guru serta murid, hal ini dirasakan dari sebagian Bapak/Ibu Guru di mana penggunaan internet jika di sekolah semua di fasilitasi oleh WIFI sekolahan, akan tetapi jika pembelajaran dari rumah semua bentuk pengeluaran internet dibebankan kepada Bapak/Ibu Guru.

Dengan demikian pernyataan di atas menunjukkan masih didapatinya faktor penghambat pelaksanaan pembelajaran jarak jauh adanya hambatan dalam proses melaksanakan pembelajaran berbasis daring tersebut dan perlunya pengkajian serta sebagai bahan evaluasi ke depannya.

\section{Kesimpulan}

Dari uraian di atas penulis menyimpulkan bahwa strategi pembelajaran jarak jauh yang dilakukan oleh SMP Plus Daarul Ahgaff dalam situasi wabah pandemi COVID-19 adalah menggunakan pemanfaatan teknologi seperti WAG, Google classrooms, Google form, penayangan video dan lain sebagainya dengan tetap guru melakukan pembelajaran kepada khalayak siswa-siswi. Adapun dampak positif dalam pembelajaran jarak jauh SMP Plus Daarul Ahgaff dalam situasi pandemi COVID-19 di antaranya: menaati anjuran pemerintah, menambah wawasan skill dalam penggunaan teknologi dalam menunjang pembelajaran, bahan Praktik mudah dijumpai, dan menghemat biaya transportasi. Sedangkan faktor penghambat PJJ SMP Plus Daarul Ahgaff dalam situasi pandemi COVID19 di antaranya: tidak semuanya siswa memiliki HP android, tidak adanya interaksi langsung guru dan murid, dan borosnya akan pengeluaran biaya internet.

\section{Daftar Pustaka}

Anitah, S. (2014). Strategi Pembelajaran Biologi. Dalam Strategi Pembelajaran (No. 570; Vol. 1, Nomor 570, hlm. 1-30). Universitas Terbuka. http://repository.ut.ac.id/4269/

Arikunto, S. (2002). Prosedur suatu Penelitian suatu Pendekatan Praktis. Rineika Cipta. 
Arsa, I. P. S. (2015). Belajar dan Pembelajaran; Strategi Belajar yang menyenangkan. Media Akademi.

Asmuni, A. (2020). Problematika Pembelajaran Daring di Masa Pandemi COVID-19 dan Solusi Pemecahannya. Jurnal Paedagogy, 7(4), 281-288.

Azzahra, N. F. (2020). Mengkaji Hambatan Pembelajaran Jarak Jauh di Indonesia di Masa Pandemi COVID-19. Center for Indonesian Policy Studies. https://doi.org/10.35497/309163

Bungin, B. (2005). Metodologi Penelitian: Format-format Kuantitatif dan Kualitatif. Airlangga University Press.

Fatimah, F. \& Andriyansyah. (2013). Raih Sukses Belajar di Pendidikan Jarak Jauh. Graha Ilmu.

Hardini, I., \& Puspitasari, D. (2015). Strategi Pembelajaran Terpadu (Teori, Konsep, dan Implementasi. Familia.

Moelong, J. L. (2009). Metodologi Penelitian Kualitatif. Remaja Rosdakarya.

Munir. (2009). Pembelajaran Jarak Jauh Berbasis Teknologi Informasi dan Komunikasi. Alfabeta.

Remiswal, \& Amelia, R. (2013). Format Pengembangan Strategi PAIKEM Dalam Pembelajaran Pendidikan Agama Islam. Graha Ilmu.

Semradova, I., \& Hubackova, S. (2016). Teacher responsibility in distance education. Procedia-Social and Behavioral Sciences, 217, 544-550.

Sudatha, I. G. W., \& Tegeh, I. M. (2015). Desain Multimedia Pembelajaran. Media Akademi. Sugiyono. (2010). Metode Penelitian Pendidikan: Pendekatan Kuantitatif, kualitatif dan $R$ $\& D$. Alfabeta.

Sukmadinata, N. S. (2010). Metode Penelitian Pendidikan. Remaja Rosdakarya.

Sutopo, A. H. (2012). Teknologi Informasi dan Komunikasi Dalam Pendidikan. Graha Ilmu. Sutrisno, H. (2003). Metodologi Riset. Andi Ofset.

Yuangga, K. D., \& Sunarsi, D. (2020). Pengembangan media dan strategi pembelajaran untuk mengatasi permasalahan pembelajaran jarak jauh di pandemi COVID-19. JGK (Jurnal Guru Kita), 4(3), 51-58. 